\title{
Decoración del gres porcelánico natural con aplicaciones de naturaleza organometálica
}

\author{
J. PORTOLÉS, J. SÁNCHEZ, C. SOLER, D. REDONDO \\ TAU CERÁMICA, TAULELL, S.A. 12006. Castellón.
}

\begin{abstract}
Los objetivos perseguidos se podrían resumir como la obtención de un nuevo producto de Gres Porcelánico que, teniendo en cuenta los atributos técnicos y estéticos de este material, potencie estas características de manera significativa y le confiera nuevos valores de gran interés. Las líneas de trabajo realizadas se han concretado en la mejora de las prestaciones técnicas inherentes al Gres Porcelánico Natural, atribuyéndole, al mismo tiempo, características hasta ahora solo presentes en el material pulido. Al mismo tiempo, se han definido nuevas aplicaciones decorativas que posibilitan la compartición simultánea de definiciones estéticas, hasta ahora no logradas con este tipo de producto, con un mantenimiento de las prestaciones del mismo.
\end{abstract}

Palabras clave: gres porcelánico, decoración, cerámica, sol gel, cristaloquímica.

\section{Decoration of natural porcelain stoneware with organometalic applications}

\begin{abstract}
The objectives aimed at could be summarised as the obtaining of a new Porcelain Stoneware product which, taking into account this material technical and esthetical attributes, emphasises those characteristics in a significant way, and provides it with new very interesting values. The working lines followed were focussed on the improvement of the technical qualities inherent to Natural Porcelain Stoneware, attributing to it, at the same time, characteristics only present, until now, in the polished material. New decorative applications have been also defined which allow the simultaneous comparison of aesthetic definitions together with a maintenance of its qualities, something never done before with this type of product.
\end{abstract}

Key works: porcelain stoneware, decoration, sol-gel, crystalo-chemistry, ceramic.

\section{INTRODUCCION}

\subsection{Características Particulares del Gres Porcelánico}

Dentro del panorama de la oferta internacional, la aparición del Gres Porcelánico en el campo de los recubrimientos cerámicos ha supuesto una de las innovaciones de producto más interesantes de los últimos años. Este material, considerado en el pasado únicamente como un producto con unas elevadas prestaciones técnicas, muestra en el día de hoy un potencial estético de extraordinario valor ${ }^{(1-3)}$.

Este nuevo producto cerámico que está alcanzando una extraordinaria expansión en los últimos años, que responde al nombre genérico de Gres Porcelánico, y que se atribuye como propio la industria italiana, tiene en nuestro país un antecedente venerable, en la fábrica valenciana de Meliana, Mosaicos Nolla, que a mediados del pasado siglo, ya producía baldosas no vidriadas, coloreadas en masa y totalmente gresificadas.

Los ambientes públicos, comerciales e industriales requieren pavimentos con elevada resistencia a la abrasión y mecánica en general, lo mismo ocurre en pavimentos de uso externo, que deben tener una elevada resistencia al desgaste, puesto que en las zonas circundantes puede existir arena $\mathrm{u}$ otro tipo de partículas que actúan como abrasivo sobre el material cerámico, favoreciendo su deterioro ${ }^{(4)}$.

\section{1- INTRODUCTION}

\subsection{Porcelain Stoneware particular characteristics}

The appearance of Porcelain Stoneware in the field of ceramic wall tiles implies one of the most interesting novelties of the product within the international demand scene in the last years. This material, only considered as a product with high technical qualities in the past, shows nowadays an aesthetic, extraordinarily valuable potentiality.

This new ceramic product, generally called Porcelain Stoneware, which has been achieving a great expansion in the last years, and which the Italian industry lays claim to, has got a venerable ancestor in our country, in the Valencian firm from Melliana called "Mosaicos Nolla". The aforementioned firm already produced mass-coloured, porcelain stoneware nonvitreous floor tiles in the middle of last century.

Public, commercial, and industrial atmospheres require floor tiles with a high abrasion length and mechanical strength. The same thing happens with external use floor tiles, which must have a high wear resistance, as sand or another kind of particles might be found around which act as abrasives on the ceramic material, thus favouring its decay. 
Los pavimentos cerámicos esmaltados más comunes (grupos BIb y BIIa) no suelen cumplir las exigencias sobre características técnicas de estas aplicaciones, por lo que frente a ellos aparece con fuerza el Gres Porcelánico (grupo Bla). Si a lo anterior se añaden las cualidades estéticas que recientemente se están desarrollando en este tipo de producto, su campo de implantación todavía crece en mayor medida, posibilitando su introducción en ambientes interiores de hogares particulares $^{(5)}$. En la Tabla I, se muestran las principales características técnicas del Gres Porcelánico.

Los datos que se muestran, indican las razones por las que este producto se diferencia del resto de materiales cerámicos. Además de su proverbial resistencia al desgaste, aparecen otras propiedades significativas, valores de absorción de agua extremadamente bajos, alta resistencia mecánica, química, a la helada y a los esfuerzos de compresión.

\section{Dificultades Técnicas y Decorativas del Gres Porcelánico.}

Aunque las cualidades técnicas del Gres Porcelánico lo hagan figurar entre los productos más versatiles del mercado, su fabricación, con una elevada componente tecnológica, está constituida por múltiples fases de complejidad elevada, que deben ser estudiadas para obtener unos mejores resultados. A continuación se expondrán algunos factores particulares.

Una de las dificultades que en mayor medida puede deteriorar la calidad del Gres Porcelánico surge cuando, con el propósito de mejorar las características estéticas del producto, se pule su superficie. Aunque tras este proceso de abrasión controlada, se obtienen superficies lisas y muy brillantes, también afloran sobre dicha superficie algunos de los poros cerrados que, de manera residual, han quedado presentes en la pieza, disminuyendo de este modo, las prestaciones superficiales del producto colocado.

Por otro lado, aun cuando el Gres Porcelánico natural apenas posea ninguna porosidad abierta, sus prestaciones superficiales pueden verse afectadas como consecuencia de la rugosidad superficial inherente a los mecanismos de conformado y sinterización de los materiales de la baldosa, como se puede ver en la figura 1. Este fenómeno, menos conocido y de menor incidencia que el caso de la microporosidad abierta del Porcelánico pulido, también debe tenerse en cuenta para calificar la adecuación al uso del material colocado.

Tanto en el caso del Porcelánico TABLE I: PORCELAIN STONEWARE TECHNICAL CHARACTERISTICS pulido como en el natural, la disminución de prestaciones super- TABLA I - CARACTERISTICAS TECNICAS DEL GRES PORCELÁNICO

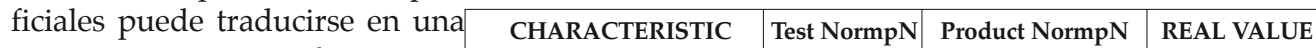
menor resistencia al ensuciamiento, mayor dificultad de limpieza y menor resistencia a la abrasión y a los agentes químicos. No obstante, es necesario señalar que, en la actualidad, las dificultades expuestas constitu yen un problema minoritario debido a los importantes avance en la mejora de las composiciones y en las técnicas de procesamiento del producto.

El análisis de lo expuesto, muestra como puede marcarse un camino hacia la mejora de las propiedades superficiales del tors will be explained.

\begin{tabular}{|c|c|c|c|}
\hline CHARACTERISTIC & $\begin{array}{c}\text { Test NormpN } \\
\text { ISO 10.545 }\end{array}$ & $\begin{array}{l}\text { Product NormpN } \\
\text { ISO 13.006 }\end{array}$ & REAL VALUE \\
\hline Water absorption & Part 3 & $\leq 0.5 \%$ & $<0.05 \%$ \\
\hline Bending Strength & Part 4 & $\geq 35 \mathrm{~N} / \mathrm{mm}^{2}$ & $>50 \mathrm{~N} / \mathrm{mm}^{2}$ \\
\hline Impact Strength & Part 5 & $\begin{array}{l}\text { Test method } \\
\text { available }\end{array}$ & $\begin{array}{l}\mathrm{r}>0.55 \text {; has } \\
\text { to be required }\end{array}$ \\
\hline Abrasion Strength & Part 6 & $<175 \mathrm{~mm}^{3}$ & $<150 \mathrm{~mm}^{3}$ \\
\hline Lineal Thermal Expansion & Part 8 & $\begin{array}{l}\text { Test method } \\
\text { available }\end{array}$ & $6.5 \times 10^{-6} \mathrm{~K}^{-1}$ \\
\hline Thermal Shock & Part 9 & $\begin{array}{l}\text { Test method } \\
\text { available }\end{array}$ & Resists \\
\hline Expansion due to humidity & Part 10 & $\begin{array}{l}\text { Test method } \\
\text { available }\end{array}$ & $<0.1 \mathrm{~mm} . / \mathrm{m}$. \\
\hline Frost Resistance & Part 12 & Required & Resists \\
\hline Chemical attack resistancet & Part 13 & $\begin{array}{l}\text { Suggested by } \\
\text { the manufacter }\end{array}$ & Resists \\
\hline Resistencia a las manchas & Part 14 & $\begin{array}{c}\text { Test method } \\
\text { available }\end{array}$ & Mín. Class 2 \\
\hline
\end{tabular}

The most common glazed ceramic floor tiles (Blb and Blla) do not usually comply with requirements on technical characteristics for those applications. This is the reason why the Porcelain Stoneware (Bla group) appears strongly as compared to them. If the aesthetic qualities recently being developed with this type of product are added to the aforementioned, its implantation field grows to an even greater extent, making it possible its introduction in the interior of private homes. Table I shows the main porcelain stoneware technical characteristics.

The data shown indicate the reasons why this product is different from the rest of ceramic materials. On top of its proverbial wear resistance, other significant properties appear, such as extremely low water absorption values, high chemical, mechanical strength to frost, and compressive stress.

\section{Porcelain Stoneware Technical and Decorative Difficulties}

Although the Porcelain Stoneware technical qualities make it figure among the most versatile products of the market, its manufacturing, with a high technological component, is constituted by highly complex multiple phases, which must be studied in order to obtain better results. Now, some particular fac-

One of the difficulties which can most deteriorate the Porcelain Stoneware quality occurs when its surface is polished in order to improve the product aesthetic characteristics. Although flat and shining surfaces are obtained after this controlled abrasion process, some closed pores remaining on the piece in a residual way appear on the surface as well, in this way decreasing the surface qualities of the fixed product.

On the other hand, even although the natural Porcelain Stoneware does not possess any open porosity, its surface qualities can result affected as a consequence of the surface roughness inherent to the tile materials forming and sintering (figure 1). This phenomenon, less well known and with a lower incidence that the case of the polished Porcelain Stoneware open microporosity must also be taken into account in order to qualify the fixed material use suitability.

In the case of the polished Porcelain Stoneware, as well as in the natural one, the decrease of surface qualities can be translated into a lower soiling resistance, more cleaning difficulty, lower abrasion length, and resistance to chemical agents. Nevertheless, it is important to mention the fact that, nowadays, the aforementioned difficulties constitute a minor problem, due to the important developments in the improvement of the compositions and in the product processing techniques.

An analysis of all the above mentioned shows how the way towards the improvement of the Porcelain Stoneware surface qualities can be directed, bearing in mind a double effect: on the one hand, the growing use of natural product as opposed to the polished one -in case both aesthetic effects could be considered equal, and, on the other hand, the decrease of the natural Porcelain Stoneware surface microroughness by means of an adequate technology. 
Gres Porcelánico teniéndose en cuenta $\perp \quad 40 \mathrm{\mu n}$ un doble efecto, por un lado el empleo creciente de producto natural frente al pulido, si se consiguiera equiparar los efectos estéticos de los mismos, y por otro lado, la disminución de la microrugosidad superficial del Gres Porcelánico natural mediante el uso de la tecnología adecuada.

Asimismo cabe considerar, que el

proceso de fabricación del material Figura 1 - morfologia de la supericie de un gres porcelánico. pulido, frente al natural, implica un Figure 1-surface morphology of the porcelain stoneware. coste energético superior y es menos respetuoso con el medioambiente por el empleo masivo de agua y la generación de residuos que precisan tratamientos posteriores de depuración y reciclado

Dificultades estéticas del producto.

Hasta hace pocos años el Gres Porcelánico era conocido como producto monocromo y generalmente producido en pequeños formatos. La investigación aplicada ha permitido individualizar tipologías que posibilitan la revalorización estética del producto, con resultados interesantes y diversificados. La mezcla de polvos y granos coloreados ha permitido obtener productos de alto valor conocidos comercialmente con el nombre de "granitos".

A partir de los años 90 empiezan a desarrollarse nuevas técnicas decorativas sobre el Gres Porcelánico, que se convierten en un objetivo prioritario en la innovación de producto. Algunas de estas técnicas están empezando a adaptarse a la producción, decoración por medio de doble carga de prensa, serigrafía, regranulaciones, relieves, pulverizados de barbotinas,... . No obstante, queda un extenso campo de experimentación y desarrollo que acometer.

En general, el sector cerámico ha venido desarrollando sus diversos productos tendiendo frecuentemente al mestizaje de sus características. Así es posible encontrar materiales rústicos que imitan los esmaltados, esmaltados que imitan los extrusionados, ...y todas las posibles variantes imaginables. En esta corriente, el Gres Porcelánico presenta notables limitaciones a priori, frente al resto de productos, puesto que sus exigentes condiciones de proceso (elevadas compactaciones, altas temperaturas de cocción, etc.) dificultan la traslación de tecnología de forma inmediata.

Asi pues, aun cuando las cualidades estéticas del Gres Porcelánico estén alcanzando cotas de extraordinaria belleza, cabe considerar que cualquier mejora, o nuevo método, que permita el enriquecimiento de los motivos decorativos aplicables, será de gran interés. Lógicamente, deberán buscarse técnicas que, sin suponer un cambio traumático de los procesos ni de las instalaciones, posibiliten una mayor definición y variedad de los diseños, y que, imprescindiblemente, mantengan al máximo e incluso mejoren las propiedades técnicas de este producto.

Por otro lado, en los últimos tiempos han aparecido en el mercado equipamientos, destinados a las etapas de decoración de las baldosas cerámicas, que aportan importantes ventajas tecnológicas de aumento de productividad y mejora en la variedad de efectos estéticos sobre el producto final. Estos dispositivos consiguen la transferencia de sistemas pigmentantes a las baldosas mediante métodos diferenciados frente a los procedimientos habituales de decoración, haciendo uso, de forma intensiva, de los recursos informáticos y las soluciones electromecánicas mas avanzadas. En contrapartida, su penetración en el proceso productivo industrial, está necesitando
It is also interesting to take into consideration that the manufacturing process of the polished material, as opposed to the one of the natural material implies a higher energetic cost and is less respectful with the environment, due to the massive use of water, and to the generation of waste products which need following processes of purification and recycling.

Study the aesthetic difficulties of the product.

Porcelain Stoneware was known as a monochrome product generally produced in small format up till some years ago. The applied research has allowed to individualise typologies which make the product aesthetic revaluation possible, obtaining interesting and diversified results. The mixture of powders and coloured grains has allowed to obtain highly valuable products commercially known as "granites".

From the 90s on, new Porcelain Stoneware decorative techniques have started to develop. They are becoming the main aim in the innovation of the product. Some of those techniques are beginning to become adapted to the production, decoration by double-load press, screen printing, relieves, slurry dusting... However, a wide research and development field to work on lays ahead.

Generally speaking, the ceramic sector has developed its different products having a tendency towards the crossbreeding of its characteristics. It is thus possible to find rustic materials imitating glazes, glazes imitating extrusions... and all conceivable variants. According to this tendency, Porcelain Stoneware presents remarkable a priori limitations, when compared to the rest of products, because the demanding process conditions (high compacting, high firing temperatures, etc...) make the immediate technology translation difficult.

In this way, even when the Porcelain Stoneware aesthetic qualities are reaching extraordinary beauty standards, any improvements or methods which enrich the applicable decorative designs will be considered of interest. It follows that some techniques will have to be searched for. Techniques which, without meaning a traumatic change of the processes or the premises, will make a higher definition and design variety possible. At the same time, they will have to keep or even improve the technical qualities of the product.

On the other hand, equipment assigned to the different ceramic tiles decoration stages has appeared in recent years, which provides important technological advantages of productivity increase and improvement in the variety of aesthetic effects on the final product. Those devices succeed in the transference of colouring systems to the tiles by means of differentiated methods as opposed to the common decoration procedures by using the most advanced computer resources and electromechanical solutions in an intensive way. But in contrast, its penetration in the industrial production process is in need of the final preparation of pigmenting agents and inks whose requirements regarding rheology, chromatic intensity, low grain size distribution, and covering power are difficult to cover by traditional inks.

As a consequence, it is very interesting to develop new pigmenting agents and inks which, apart from conferring adequate technical and esthetical properties to the tiles, meet the new decoration systems requirements which imply the technological progress at this process stage. 
de la puesta a punto de agentes y tintas pigmentantes cuyos requerimientos en terminos de reología, intensidad cromática, baja granulometría y poder cubriente, dificilmente pueden ser cubiertos por las tintas tradicionales.

En consecuencia, resultará interesante el desarrollar nuevos agentes pigmentantes y tintas que, al margen de conferir unas adecuadas prestaciones técnicas y estéticas a las piezas, satisfagan los requerimientos de los nuevos sistemas de decoración que suponen el progreso tecnológico, presente actualmente, en esta etapa del proceso.

\subsection{Recubrimientos vitrocristalinos de baldosas cerámicas que emplean precursores no tradicionales.}

En el campo de la tecnología de pavimentos y revestimientos cerámicos aparecen muchos problemas relacionados con la superficie y la interfase de los materiales relacionadas con las propiedades mecánicas (dureza, resistencia a la abrasión,...), resistencia química y ataques de manchas, así como requerimientos en las propiedades ópticas de los mismos (transparencia, cristalizaciones, separación de fases, ...).

Por otra parte, la obtención de materiales con propiedades superficiales relevantes obliga, en general, a mantener una composición homogénea de todo el vidriado con lo que ésto supone de encarecimiento de las materias primas, así como las pérdidas económicas y problemas medioambientales que supone el tener que procesar, mediante fritado, este tipo de materiales (usualmente refractarios y con cierta inercia a vitrificar) en las cantidades correspondientes a toda la capa de vidriado.

Un segundo aspecto, relacionado como el caso anterior, con la química y física de superficies, es la problemática relacionada con la interacción de la interfase vidriado-soporte. Si bien los problemas de adherencia (cuarteado, desconchado, recogido de superficies del vidriado, ...) no son únicamente debidos a fenómenos de superficie (disimilitud del coeficiente de expansión térmica), que duda cabe que la posibilidad de modificar las relaciones de interfase mediante la interposición de un agente con gran poder cubriente y compatibilidad entre fases es un objetivo de gran interés en el sector que nos ocupa.

Las posibilidades que abren las nuevas tecnologías en materiales, desde el punto de vista tecnológico, para la obtención de recubrimientos cerámicos de altas prestaciones, se pueden resumir en lo siguiente:

- mínimo espesor de capa.

- alta reactividad química. lo que permite su compatibilidad con los procesos cerámicos de ciclo rápido y en monococción.

- inercia frente a determinados sistemas que impida su dilución y pérdida de identidad química.

- alto poder cubriente y su compatibilidad con el soporte cerámico.

- granulometrías más finas consiguiendo mayor poder de definición.

- posibilidad de modular las propiedades requeridas en función de su uso, abriendo nuevos caminos en la investigación de materiales bajo el punto de vista de la Ingeniería Molecular:

\section{ESTRUCTURA $\leftrightarrow$ COMPOSICIÓN $\leftrightarrow$ PROPIEDADES}

A la vista de los requerimientos del sector productivo, es casi una necesidad, el plantear hoy en día nuevos métodos no convencionales de síntesis y procesado, tales como los métodos
1.2. Glass-ceramic cover of ceramic floor tiles using non-traditional precursors.

Many problems related to the materials surface and interface appear in the technological field having to do with mechanical properties, such as hardness, abrasion length, chemical resistance, and spot attack, as well as optical properties requirements, such as transparency, crystallisation, and phase separation.

On the other hand, the obtaining of materials with relevant surface properties makes it necessary to keep a glaze homogeneous composition, which implies a price increase of raw materials. As well as economical losses and environmental problems generated by the fritting of those materials in the quantities corresponding to every glaze coat (usually refractory and tending to vitrify).

Another aspect related to surface chemistry and physics to be taken into account refers to the problems generated by the interaction interface glaze-body. Even although the adhesion problems -as for instance crazing cracks, peeling, and glaze surface contraction- are not only due to surface phenomena (thermal expansion coefficient dissimilarity), there is no doubt that the possibility of modifying the interface relations by the interposition of an agent with a great covering power, and compatibility between phases is a very interesting objective in this sector.

The possibilities the new materials technologies open from a technological point of view for the obtaining of high quality ceramic glazes can be summarised as follows:

- minimum layer thickness

- high chemical reactivity, which allows its compatibility with fast firing cycle and single firing ceramic processes.

- Inertia to some systems thus preventing its dilution and loss of chemical identity.

- High covering power and its compatibility with the ceramic body.

- Thinner grain size thus obtaining a greater definition power.

- Possibility of modulating the properties required according to its use, opening new means in materials research as regards Molecular Engineering:

\section{STRUCTURE $\leftrightarrow$ COMPOSITION $\leftrightarrow$ PROPERTIES}

Bearing the productive sector requirements in mind, it is nowadays almost necessary to create new non-conventional synthesis and processing methods, such as sol-gel methods, which can contribute to the development of glazes with improved characteristics. Taking this aim into account, the necessary research actions will have to be undertaken in order to adapt these technologies and make them compatible with the process conditions and the operation variables of the industrial production system.

Although the possibilities of the aforementioned precursors preparation technique permit the obtaining of an unlimited materials range with differentiated characteristics according to a diverse design of properties, the definition of three families of precursors has been thought convenient. This classification is shown in the following Table:

In a general way, it could be said that these materials permit to obtain a crystalline film and a high technological quality on 
sol-gel, que pueden permitir el TABLA II - PRECURSORES SELECIONADOS, ASPECTO DE LA PIEZA ACABADA Y Porcelain Stoneware floor tiles. desarrollo de cubrientes con TIPOLOGÍA DE APLICACIÓN REALIZADA. características mejoradas respec-

to a los actualmente existentes. TABLE II - PRECURSORS CHOOSE ASPECT OF THE FINISHED PIECE AND TYPOCon este objetivo, será necesario ${ }^{\text {LOGY OF APPLICATION MADE. }}$ emprender las acciones de investigación oportunas para conse guir que estas tecnologías puedan adaptarse y hacerse compatibles con las condiciones de proceso y variables de operación del sistema productivo industrial.

\begin{tabular}{|c|c|c|}
\hline REFERENCE & ASPECT & DECORATION \\
\hline PZ-352 & Matt & Dusting \\
PA-520 & Semi-Matt & $\begin{array}{c}\text { Dusting } \\
\text { Screen Printing } \\
\text { Dusting } \\
\text { Screen Printing }\end{array}$ \\
\hline PC-787 & Glossy & Sci \\
& &
\end{tabular}

It is worth pointing out the fact that, even in spite of the high covering power of the surfaces generated -which might be attributed to their vitreous naturethey are crystalline to a high degree, as the following chart shows. In it, the number of accounts of the quartz main peak obtained for each of the developed precursors is presented. Once applied on the floor tile it has been measured, and then submit-

\section{CARACTERISTICAS DE LA TECNICA}

\subsection{Precursores empleados.}

El sistema parte del empleo de nuevos materiales, preparados a partir de disoluciones coloidales estabilizadas, en forma de películas de unas pocas micras de espesor y con las propiedades que debe reunir, diseñadas a priori, en función de elementos compatibles con la composición del soporte que se pretende cubrir ${ }^{(6)}$.

Empleando un ciclo de calcinación adecuado, se desarrolla una película cubriente que mejora las prestaciones técnicas del Gres Porcelánico actualmente comercializado, en términos de resistencia mecánica, ataque químico y resistencia a las manchas, etc...

También se han estudiado las posibilidades de aplicación de este producto a través de pulverización y de serigrafía, en éste último caso, potenciando los aspectos estéticos del Gres Porcelánico actual, al permitir la utilización de nuevas técnicas decorativas para este producto, que posibilitan la obtención de una gama de efectos estéticos de gran definición y variedad.

Aunque las posibilidades de la técnica de preparación de los precursores mencionados, permite la obtención de una gama ilimitada de materiales de características diferenciadas, de acuerdo con el diseño de propiedades que se desee, para el desarrolo de estos trabajos se ha estimado oportuno la definición de tres familias de precursores, como se muestra en la Tabla II.

De manera general, se podría señalar que estos materiales permiten la obtención de una película de naturaleza vitrocristalina y elevadas prestaciones tecnológicas sobre baldosas de Gres Porcelánico.

Cabe destacar que, pese al elevado poder cubriente de las superficies generadas, que podría atribuirse a su caracter vítreo, presentan un grado de cristalinidad bien marcado, en la G.P. Natura figura 2, se presenta el número de cuentas del pico principal del cuarzo obtenido para cada uno de los precursores desarrollados y medido una vez aplicado sobre la baldosa $y$ sometido a cocción.

Por sus características, estos nue-difractograma.

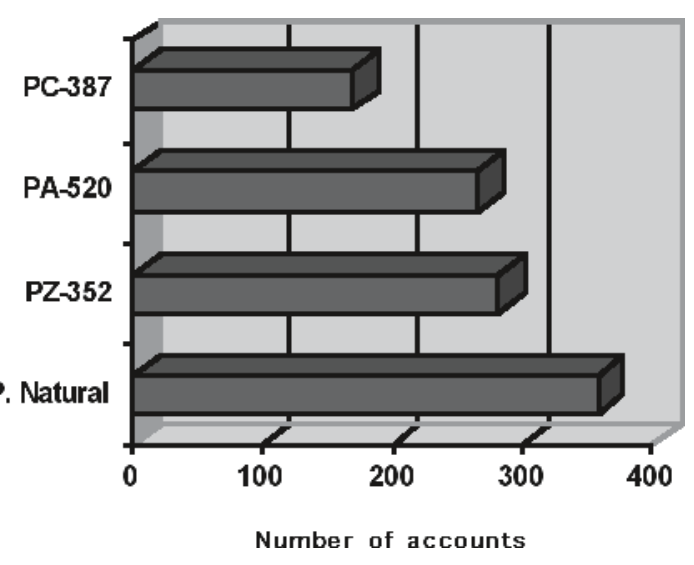

vos precursores de recubrimientos

cerámicos, presentan una serie deFigure 2 - schematic representation of the number of accounts ventajas frente a los actuales, de las of the quartz main peak $\left(\alpha-\mathrm{SiO}_{2}\right)$, went through by $\mathrm{X}$ ray.

\section{TECHNIQUE CHARACTERISTICS}

\subsection{Precursors used.}

The system starts from the use of new materials prepared from stabilised colloidal solutions shaped like films a few microns thick, and with the adequate properties according to elements compatible with the composition of the body to be covered.

By using an adequate firing cycle, a covering film is developed. This film improves the technical qualities of the Porcelain Stoneware nowadays commercialised, such as for instance mechanical strength, chemical attack, and spots resistance.

The application possibilities of this product by dusting and screen printing have also been studied. In the case of screen printing, the Porcelain Stoneware esthetical aspects have been strengthened, as they permit the use of new decorative techniques, and provide a wide range of aesthetic effects with a high definition and variety.

Although the possibilities of the aforementioned precursors preparation technique permit the obtaining of an unlimited range of materials with differentiated characteristics according to a diverse design of properties, the definition of three families of precursors has been thought convenient. This classification is shown in the following Table II:

In a general way, it could be said that these materials permit to obtain a crystalline film and a high technological quality on PorcelainStoneware floor tiles.

It is worth pointing out the fact that, even in spite of the high covering power of the surfaces generated -which might be attributed to their glassy nature- they are crystalline to a high degree, figure 2 . In it, the number of accounts of the quartz main peak obtained for each of the developed precursors is presented. Once applied on the floor tile it has been measured, and then submitted to the firing process.

According to their characteristics, these new ceramic glazes precursors present a series of advantages when compared to the present ones. Some of the most outstanding are: 
que cabría destacar, de entre otras, las siguientes:

-Ahorros energéticos y medioambientales, al posibilitar eliminar etapas intermedias de calcinación, como es el caso del fritado para la obtención de la frita y su acondicionamiento posterior hasta la obtención del esmalte (molturación de la frita con los aditivos y su puesta a punto para su posterior aplicación). En los aspectos medioambientales hay que incidir en el ahorro de agua en los procesos de obtención de la frita y del esmalte, eliminación de agentes tóxicos o agresivos como lo son los mineralizadores.

- Posibilidad de diseño de propiedades a reunir en el producto final, diseñadas a priori en la formulación del mismo.

-Alto grado de homogeneización (a escala molecular), ya que se trabaja en partículas de tamaño de los coloides.

- Menores costes que los productos tradicionales, ya que su elaboración sólo requiere un único procesado de naturaleza química.

- Buena adherencia, por su alto grado de compatibilidad, con el soporte cerámico, control de penetración en el mismo y alto poder cubriente.

- Desarrollo del grado de poder de reflexión (brillos), modulado según necesidades, manteniendo una mayor economía, con menores dificultades técnicas y medioambientales frente al pulido.

\subsection{Naturaleza de las aplicaciones decorativas.}

Para llevar a cabo las aplicaciones de los precursores señalados sobre las baldosas de Gres Porcelánico, se ha efectuado un trabajo de desarrollo, cuyo objetivo ha sido conseguir la compatibilidad del empleo de estos materiales de alta tecnología, con el proceso industrial en planta.

Efectivamente, la naturaleza esencialmente distinta de estos precursores, frente a los componentes habituales empleados en el proceso industrial tradicional, ha provocado la necesidad de cambios en el proceso de adaptación de los materiales, labor para la cual se ha contado con el asesoramiento del Departamento de Química Inorgánica y Orgánica de la Universidad Jaume I de Castellón. Por un lado, se ha incidido en la definición de los mismos precursores, atendiendo a los factores de: estabilidad de las disoluciones, acondicionamiento reológico, tensión superficial en frio, etc.... Por otro lado, sobre los parámetros de control de la línea industrial de aplicación: elección y configuración de aplicadores, distribución y secuencia de las aplicaciones, etc...

El resultado final ha permitido concluir en el hecho de que se ha conseguido una total integración de estos nuevos precursores en las líneas productivas de una planta industrial, con escasas modificaciones sobre la configuración tradicional de las mismas. Este logro merece ser destacado, en nuestra opinión, si se considera que el factor viabilidad ha de tenerse especialmente en cuenta en cualquier trabajo de transferencia de tecnología, donde precisamente los esfuerzos de adaptación son los más importantes.

Como resultado del trabajo, se plantean dos tipos fundamentales de aplicación, la pulverización, que confiere un factor de protección ideal sobre las baldosas y la serigrafía, que permite la obtención de definiciones estéticas inalcanzables, hasta este momento, sobre Gres Porcelánico.

\section{PULVERIZACION}

Empleo del aerógrafo en línea con boquilla fina
- Energetic and environmental savings, due to the fact that they eliminate intermediate firing stages, as in the case of the fritting for the obtaining of the frit and its posterior preparation for the obtaining of the glaze (frit grinding with additives and its final preparation for the posterior application). Regarding the environmental aspects, it is important to save water in the processes for the obtaining of the frit and the glaze, and the elimination of toxic or aggressive agents such as mineralizers.

- Possibility of designing the final product properties a priori and in the formulation itself.

- High homogenisation degree (at a molecular scale), as the study is carried out with particles of the colloids size.

- Lower costs than traditional products, as their manufacturing only requires one processing of a chemical nature.

- Good adherence to the ceramic body due to its high degre of compatibility, control of penetration into the ceramic body, and high covering power.

- Development of the reflection power (gloss), modulating it according to need, and keeping a better economy, with less technical and environmental difficulties when compared to polishing.

\subsection{Nature of the decorative applications.}

In order to carry out the applications of the aforementioned precursors on the Porcelain Stoneware floor tiles, a development work has been realised. Its main objective being to achieve the compatibility of the use of these high technology materials with the actual industrial process.

In fact, the essentially different nature of these precursors, as opposed to the usual components used in the traditional industrial process, has provoked the necessity of changes in the materials adaptation process. It is for this task that the assessment of the Inorganic and Organic Chemistry Department (University Jaume I) has been asked for. On the one hand, the precursors have been defined taking into account factors such as: solution stability, rheological conditioning, and cold surface tension. On the other hand, some work has also been carried out on the control parameters of the application industrial line: selection and configuration of applicators, and distribution and sequencing of the applications.

The final result allows us to conclude with the fact that a total integration of those new precursors in the actual industrial production lines has been achieved, with very few modifications on the production lines traditional configuration. This is an achievement worth pointing out, considering that the viability factor has to be especially taken into account in any study about technology transference, where the adaptation efforts are the most important.

As a result of the present work, two fundamental types of applications are proposed: dusting, which confers an ideal protection factor on the floor tiles, and screen printing, which allows us to obtain aesthetic definitions on Porcelain Stoneware, unattainable up till now.

\section{DUSTING}

Use of the aerograph in line with a thin spray nozzle. Stabilised low density and viscosity precursor. Solution: NON Suspension.

Applied on a hot piece $\left(40-50^{\circ} \mathrm{C}\right)$ with a quantity of $20-25 \mathrm{~g}$ $(30 \times 30 \mathrm{~cm})$. 
Precursor estabilizado de baja TABLA III - COMPARACIÓN DE LA VANTAJAS DE LA APLICACIÓN A TRAVÉS densidad y viscosidad. DE LA PRESENTE LINEA DE ESTUDIO Y LA DE SALES SOLUVES.

Disolución : NO Suspensión

Aplicado sobre pieza caliente TABLE III - COMPARISON OF THE APPLICATION ADVANTAGES THROUGH THE $\left(40-50{ }^{\circ} \mathrm{C}\right)$ con una cantidad de PRESENT STUDY LINE AND THE SOLUBLE SALTS.

$20-25 \mathrm{~g} 30 \times 30 \mathrm{~cm}$

Compatible con serigrafias

consigue una protección de altas prestaciones

\section{SERIGRAFIA}

Empleo de máquina serigráfica convencional, ajustada convenientemente.

Precursor en seco + Vehiculo compatible + pigmento calcinado adaptado (bajísima granulometria).

Pantalla serigráfica convencional, hilaje mínimo 62, hilaje máximo no determinado, límite pigmento calcinado (gran definición)

Gran gama de colores y efectos mate, semimate y brillo. Posibilidad de interacción y efectos cromáticos entre aplicaciones.

Secado muy rápido, posibilidad de verias aplicaciones muy próximas

Combinación, en cualquier orden, con protecciones pulverizadas

En cuanto a las características de la línea productiva donde se efectuan las aplicaciones, cabría señalar que presenta notables ventajas frente a la tradicional línea de decoración de Gres Porcelánico mediante sales solubles (tabla III).

\section{DESCRIPCION DEL PROCEDIMIENTO DE TRABAJO}

\section{PRECURSORES}

A la hora de diseñar los precursores del recubrimiento cerámico, se han tenido en cuenta los requerimientos generales anteriormente enunciados y que pueden concretarse en los siguientes puntos:

-compatibilidad con el ciclo productivo, a la hora de la selección de ciclos y temperaturas.

-aplicación del material sin requerir procedimientos que hagan mas complejo el procesado de los productos tradicionales.

-requerimientos de altas prestaciones técnicas del cubriente: mejorar las propiedades mecánicas, químicas y de ataque de manchas del gres porcelánico actualmente producido.

-posibilidades de diseño, como son la compatibilidad con pigmentos cerámicos tradicionales, aplicación en técnicas serigráficas, etc...

-desarrollo de propiedades ópticas de reflexión con estos cubrientes, que posibiliten el poder obviar los sistemas de pulido. En este caso se han planteado dos vias de producción: un producto cubriente de características opacas "mates" y un segundo producto "brillante".

-cumplimiento de las normativas medioambientales de los precursores utilizados.

Cabe destacar especialmente, que los precursores preparados en sus variantes PZ-352, PA-520 y PC-787 han sido estabi-
Compatible with screen printings, it achieves a high quality protection.

SCREEN PRINTING SOLUBLE SALTS APPLICATION LINE

- Considerable dimension.

- It is advisable not to exceed the quantity of four applications.

- The applications must not be very close from one another.

- Intensive use of water (airless).

- High dependence on the piece temperature.

- Line with a great variety of machines, such as horizontal dryers...

- Curvature problems can appear.

- Specific firing cycles for each model.

- Need to polish.

- Uncertainty about the results. dusted protections.

Use of a conventional screen printing machine, conveniently adjusted.

Dry precursor + compatible vehicle + adapted burnt pigment (very small particle size).

Conventional printing screen, weave minimum 62, maximum non-determined, limit burnt pigment (high definition).

Wide range of colours, and matt, semi-matt, and gloss effects. Possibility of interaction and chromatic effects among applications.

Very fast drying, possibility of several very close applications.

Combination, in any order, with

With regard to the characteristics of the production line where the applications are carried out, it is worth mentioning the fact that it presents outstanding advantages as contrasted with the traditional soluble salts Porcelain Stoneware decoration line (table III).

\section{DESCRIPTION OF THE WORKING PROCEDURE}

\section{PRECURSORS}

When it came to designing the ceramic glazes precursors, the aforementioned general requirements were taken into account. They can be summarised as follows:

Compatibility with the production cycle, when it comes to selecting the cycles and temperatures.

Application of the material with no need of procedures which might difficult the processing of the traditional products.

Requirements for high technical qualities of the glaze: to improve the mechanical, chemical, and spot attack properties of the porcelain stoneware being nowadays produced.

Possibilities of design, such as compatibility with traditional ceramic pigments, and application in screen printing techniques.

Development of reflection optical properties with these coverings, which permit to avoid the polishing systems. Two systems of production have been proposed in this case: a covering product with 'matt' opaque characteristics, and a 'glossy' product.

Observance of the environmental regulations in the precursors used.

It is worth mentioning that the precursors prepared according to their variants PZ-352, PA-520, and PC-787, have been stabilised and conditioned in such a way that their use in the industrial process is carried out very effectively, in their solving variants for the dusting with a protector effect as well as in their screen printing application, for the obtaining of decorations with high qualities. 
lizados y acondicionados de forma que su empleo en el proceso industrial se puede llevar a cabo de forma totalmente efectiva, tanto en sus variantes de disolución para la pulverización con efecto protector, como en la aplicación serigráfica, para la obtención de decoraciones de altas prestaciones.

\section{DISEÑO}

Con objeto de mostrar las diferentes posibilidades de la técnica expuesta, se han preparado dos tipos fundamentales de productos.

Aplicaciones con efecto protector, provenientes de un pulverizado de los distintos precursores sobre las baldosas de Gres Porcelánico natural en sus variantes base y blanco. En este caso se pretende mostrar el incremento de propiedades tecnológicas de las superficies obtenidas con un perfecto acabado superficial en sus tres variantes:

$\begin{array}{ll}\text { Efecto mate: } & \text { PZ-352 } \\ \text { Efecto semi-mate: } & \text { PA-520 } \\ \text { Efecto brillo: } & \text { PC-787 }\end{array}$

En este caso, será intersante comparar las propiedades y apariencia de estos productos con las de las baldosas de Gres Porcelánico pulido y natural.

Para la obtención de variantes decorativas que empleen la decoración serigráfica como elemento fundamental, se han efectuado las siguientes posibilidades.

Aplicaciones serigráficas sobre porcelánico natural

Aplicaciones serigráficas junto con aplicaciones protectoras de cada uno de los precursores desarrollados

Aplicaciones serigráficas con un elevado porcentaje de recubrimiento, sobre un ambiente

En todos los casos, el procedimiento de obtención de los diseños, fue el habitual en las técnicas tradicionales de fabricación, lo que da idea del elevado grado de adaptación de la técnica de aplicación conseguido como consecuencia del trabajo, en la figura 3 se presenta un ejemplo.

\section{CARACTERISTICAS DE LOS PRODUCTOS OBTENIDOS}

Los productos obtenidos presentan una notable mejora de prestaciones frente a las baldosas de Gres Porcelánico tradicional en sus variantes natural y pulido. Asimismo, las técnicas decorativas desarrolladas permiten la obtención de toda una nueva variedad de acabados estéticos de gran definición y cromatismo frente a las decoraciones tradicionales con sales solubles, y todo ello sin renunciar a las prestaciones técnicas del producto.

La observación de la microestructura superficial de los recubrimientos obtenidos (figura 4), posibilita la comprensión del comportamiento del producto, frente a los ensayos habituales de adecuación al uso.

De la observación de la microestructura superficial de los distintos materiales

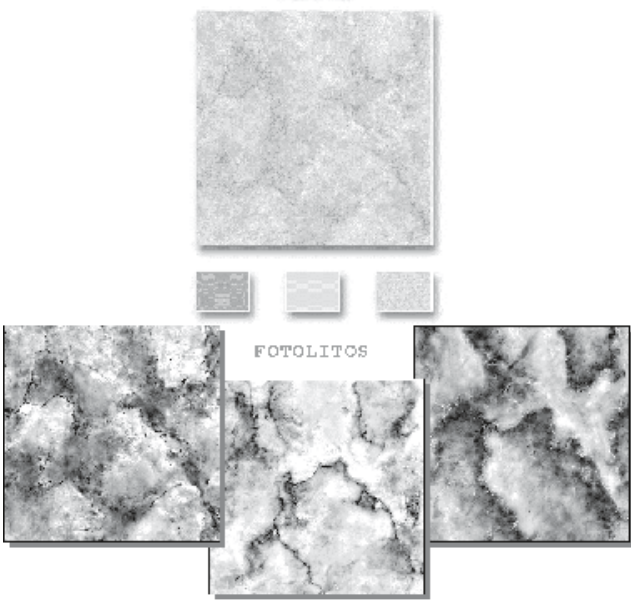
obtenidos es posible apreciar cómo, en Figura 3 - pieza decorada y los fotolitos con la sepageneral, la porosidad de las superficies ración de colores. obtenidas, es mucho menor que la del

Gres Porcelánico pulido. Figure 3 - decorated pied
En relación con el Gres Porcelánico the colour separation. on a design line.

\section{DESIGN}

In order to show the different possibilities of this technique, two fundamental types of products have been prepared.

Applications with a protector effect, from the dusting of the different precursors on the natural porcelain stoneware floor tiles in its base and white variants. The increase of the technological properties of the surfaces obtained with a perfect finish in three variants is shown in this case:

$$
\begin{array}{ll}
\text { - Matt effect: } & \text { PZ-352 } \\
\text { - Semi-matt effect: } & \text { PA-520 } \\
\text { - Gloss effect: } & \text { PC-787 }
\end{array}
$$

The comparison of those products' properties and appearance with the ones of the natural and polished Porcelain Stoneware floor tiles will be very interesting.

The following possibilities have been carried out in order to obtain the decorative variants that use the screen printing decoration as a fundamental element.

Screen printing applications on natural porcelain stoneware.

Screen printing applications together with applications protecting every precursor developed.

Screen printing applications with a high percentage of glaze,

In all these cases, the procedure for the obtaining of the designs was the usual one in the traditional manufacturing technique, which shows the high degree of adaptation of the application technique obtained thanks to the present work (figure 3).

\section{CHARACTERISTICS OF THE PRODUCTS OBTAINED}

The products obtained present an outstanding improvement of performance qualities as opposed to the traditional porcelain stoneware floor tiles in their natural and polished variants. In the same way, the decorative techniques developed permit to obtain a whole new variety of aesthetic finishes with a high definition and chromatism, as contrasted with the soluble salts traditional decorations, and, what is more, without having to give up the technical performance qualities of the product.

The observation of the surface microstructure of the glazes obtained makes the understanding of the product behaviour possible when compared to the usual tests of use suitability (figure 4 ).

When observing the surface microstructure of the different materials obtained, it can be appreciated how, generally speaking, their surface porosity is much lower than the one of the polished Porcelain Stoneware.

Regarding the natural Porcelain Stoneware, it is worth pointing out how the surface microroughness present in this product is much higher than the one in the surfaces treated with the specific precursors.

Bearing the aforementioned analysis in mind, these new materials soiling behaviour is expected to be very satisfactory, as the results in the following Table show.

According to the analysis of the data obtained, the behaviour of those products regarding spots is excellent, as well 
natural, cabe destacar cómo la micro-rugosidad superficial presente en este producto, es mucho mayor que en las superficies tratadas con los precursores específicos.

Del análisis de lo anteriormente expuesto, cabe esperar que el comportamiento frente al ensuciamiento de estos nuevos materiales sea muy satisfactorio, como así lo refrendan los resultados expuestos en la tabla IV.

Del análisis de los datos obtenidos, es necesario destacar el excelente comportamiento frente a las manchas que presentan estos productos y su resistencia a la abrasión, con las consabidas reservas a la idoneidad de los métodos PEI y MOHS para estimar la adecuación al uso de las baldosas cerámicas.

Cabe señalar que, si bien la normativa respecto al ensayo de resistencia a las manchas según Figure 4 - superficial aspect of some floor tiles. ISO, por sus características, no permite diferenciar entre el comportamiento de los productos obtenidos y el Gres Porcelánico natural o pulido, los ensayos realizados en nuestros laboratorios han demostrado, un comportamiento sensiblemente mejorado de los nuevos recubrimientos frente a los tradicionales. Este hecho, por otra parte, era previsible tras la observación de la microestructura superficial de las baldosas obtenidas.

Otro parámetro de gran importancia en la valoración de las cualidades técnicas de las superficies cerámicas es la Microdureza Vickers. Este parámetro, determinado sobre los nuevos materiales, supera con creces a los valores obtenidos en los tradicionales. De este modo puede afirmarse que las prestaciones técnicas obtenidas darán como resultado final un comportamiento mejorado respecto al del Gres Porcelánico tradicional, que por si mismo resulta netamente superior al del resto de recubrimientos cerámicos. Y lo anterior, alcanza una especial importancia al considerar que, unido a estas prestaciones tecnológicas, se encuentran unas posibilidades estéticas prácticamente ilimitadas, en cuanto a definición de los diseños y variedad cromática.

Por otro lado, los valores de brillo alcanzados con las diferentes aplicaciones obtenidas, permiten disponer de un abanico de posibilidades muy extenso, a la hora de buscar efectos de contraste brillo-mate, cuya
TABLA IV - VALORES ALCANZADOS DE LAS PRUEBAS DE RESITENCIA MECÁNICA Y MANCHAS.

TABLE IV - VALUES REACHED BY THE MECHANICAL RESISTANCE TRIAL AND SPOTS.

\begin{tabular}{|l|c|c|c|c|c|}
\hline REFERENCE & $\begin{array}{c}\text { GLOSS } \\
\mathbf{6 0}^{\mathbf{0}}\end{array}$ & $\begin{array}{c}\text { VICKERS } \\
\text { MICROHARDNESS }\end{array}$ & $\begin{array}{c}\text { PEI } \\
\text { ABRASSION(*) }\end{array}$ & $\begin{array}{c}\text { MOHS } \\
\text { HARDNESS }\end{array}$ & $\begin{array}{c}\text { ISO SPOTS } \\
\mathbf{( 1 0 5 4 5 , p 1 4 )}\end{array}$ \\
\hline PZ-352 & 4.5 & 680 & IV & $7 \pm 1$ & 5 \\
\hline PA-520 & 19.2 & 674 & IV & $6 \pm 1$ & 5 \\
\hline PC-787 & 70.3 & 640 & IV & $6 \pm 1$ & 5 \\
\hline $\begin{array}{l}\text { Screen } \\
\text { Printing }\end{array}$ & Variable & $640-680$ & IV & $6 \pm 1$ & 5 \\
\hline $\begin{array}{l}\text { Natural } \\
\text { Porcelain } \\
\text { Stoneware }\end{array}$ & 4.9 & 573 & & & \\
\hline $\begin{array}{l}\text { Polished } \\
\text { Porcelain } \\
\text { Stoneware }\end{array}$ & 61.4 & 519 & - & $7 \pm 1$ & 5 \\
\hline
\end{tabular}

$\left(^{*}\right)$ Those products do not usually take the PEI method into account. In spite of it, it is included here due to its wide diffusion. ding to the new materials, amply exceeds the values obtained following the traditional ones. In this way, it can be said that the performance qualities obtained will provide an improved behaviour if compared to the ones of the traditional Porcelain Stoneware. It is, in itself, clearly superior to the one of the rest of ceramic glazes. All this has a special importance if we consider that, together with the technical performance qualities there exist aesthetic possibilities almost unlimited regarding design definition and chromatic variety.

On the other hand, the gloss values reached with the different applications obtained provide a wide range of possibilities, when it comes to look for effects gloss-matt. The attainment of those effects, by means of the Porcelain Stoneware processing habitual techniques implies the use of expensive low-relief pressing and differential polishing stages.

The floor tiles obtained by screen printing using the precursors developed display excellent technological properties as well as extraordinary decorative possibilities.

Indeed, the use of very low grain size suspensions with a high covering power, together with a big amount of threads, permits the decoration of the Porcelain Stoneware with unthinkable precision, definition, and colouring. More so, if one bears in mind the fact that this technique permits the use of any of 
consecución, mediante las técnicas habituales de procesamiento del Gres Porcelánico implican el empleo de costosas etapas de prensado en bajo relieve y pulido diferencial.

En cuanto a las características de las baldosas obtenidas mediante el empleo de los precursores desarrollados en forma de serigrafía, cabe señalar las excelentes propiedades tecnológicas obtenidas pero, fundamentalmente las posibilidades decorativas existentes. Efectivamente, el empleo de suspensiones de granulometría muy baja y alto poder cubriente, junto con pantallas serigráficas de un gran número de hilos, permite la decoración del gres Porcelánico con una precisión, definición y cromatismo impensables hasta el momento, más si cabe, si se tiene en cuenta que la técnica permite el empleo de cualquier pigmento cerámico habitual.

Por otro lado, el hecho de que las tintas serigráficas obtenidas, no precisen de refinamiento ni post-molturación para su preparación, representa importante ventajas en términos de tiempo y productividad.

En la figura 5, se representa la evolución del perfil de microdureza obtenido a lo largo de una trayectoria fijada sobre una baldosa de Gres Porcelánico serigrafiado, pudiéndose apreciar los extraordinarios valores alcanzados y el factor protector desempeñado, por estos nuevos materiales.

\section{CONCLUSIONES}

Los resultados obtenidos, permiten afirmar que se ha logrado mejorar las propiedades técnicas del Gres Porcelánico, en sus vertientes, mecánica, química y de adecuación al uso.

Asimismo, se ha logrado aportar valores estéticos al Gres Porcelánico, por vías distintas de las convencionales

Frente a la dicotomía existente entre propiedades técnicas y belleza de las superficies de Gres Porcelánico natural y pulido, se ha alcanzado una síntesis, que permitirá disponer de superficies de alto brillo, asimilables al pulido en apariencia y superiores en la cuantificación de sus parámetros técnicos, respecto del Gres Porcelánico natural.

Las baldosas de Gres Porcelánico, sometidas a variadas aplicaciones decorativas, han mantenido y a veces superado, las buenas propiedades técnicas inherentes al Gres Porcelánico natural.

La traslación de las técnicas aplicativas a las líneas de trabajo industrial se ha logrado de manera adecuada. Es más, probablemente las técnicas aplicativas de nueva generación sintonicen eficazmente con la utilización de estos nuevos productos.

Las mejoras en ahorro energético y el respeto medioambiental y ecológico frente a la tecnología usual, constituyen una conclusión evidente y satisfactoria.

El diseño a priori de las propiedades fundamentales de las baldosas, haciendo uso de herramientas avanzadas, como la ingeniería molecular, es una camino que permitirá obtener propiedades previsibles y reproductibilidad elevada del producto final.

La compatibilidad alcanzada entre las nuevas técnicas y nuestras líneas de producción, permiten abrir un horizonte donde la profundización de las mismas y su uso sistemático y tenaz, permita aprovechar los logros del pasado para consolidar nuevas soluciones.

Estamos en la era de la cerámica y es justo que el desarrollo científico se aproxime a las líneas de producción. En este contexto, diseñar baldosas bellas con excelentes propiedades técnicas, partiendo del conocimiento y el desarrollo científico, debe ser un objetivo paradigma para nuestro sector cerámico. the common ceramic pigments.

On the other hand, the fact that the printing inks obtained do not necessarily have to be postground, represents an important advantage in terms of time and productivity.

Figure 5 shows the evolution of the microhardness profile attained through a trajectory fixed on a screen-printed Porcelain Stoneware floor tile. In it, the extraordinary values and the protective factor obtained by the new materials can be observed.

\section{CONCLUSIONS}

The results achieved allow us to state that it has been possible to improve the technical properties of the Porcelain Stoneware from a mechanical, chemical, and use-suitability point of view.

It has also been possible to contribute aesthetic values to the Porcelain Stoneware by means different from the traditional ones.

A synthesis providing surfaces with a high gloss, similar to the polished ones -and superior in the quantification of their technical parameters, has been attained as opposed to the existent dichotomy between technical properties and beauty of the Porcelain Stoneware surfaces, natural as well as polished.

Porcelain Stoneware floor tiles, when submitted to different decorative applications, maintained -sometimes exceeded- the good technical properties inherent to the natural Porcelain Stoneware.

The translation of those techniques able to be applied to industrial production lines has been successfully achieved. What is more, the new generation techniques able to be applied will probably suit the use of those new products in an effective way.

The improvements regarding the energetic savings and the environmental and ecological respect, when compared to traditional technology, constitute an evident and satisfactory conclusion.

The a priori design of the floor tiles fundamental properties by using developed tools, such as molecular engineering, is a means which will permit to obtain foreseeable properties and high reproducibility of the final product.

The compatibility attained between the new techniques and production lines permit to broaden horizons where their study and systematic use would allow to take advantage of past achievements in order to consolidate new solutions.

We are in the era of ceramics, and it is just fair that scientific development gets closer to production lines. In this context, the designing of beautiful floor tiles with excellent technical properties, from the knowledge and scientific development point of view, must be the paradigmatic objective for our ceramic sector. 


\section{BIBLIOGRAFÍA / REFERENCES}

1. C. Palmonari, "Il gres Porcellanato" Ed. Castellarano Fiandre Ceramiche SpA, Centro Cerámico, Boloña (Italia), 1989.

2. G. Biffi, "Il gres porcellanato. Manuale di fabricacione e techniche di impiego", Ed. Gruppo Editoriale Faenza Editrice SpA, Faenza (Italia), 1997.

3. G. Casolari, "Porcellanato: effetti estetici con il caricamento multiplo", Ceramic World Review, 19 , 84-88 (1996).

4. J.E. Enrique, J.L. Amorós, A. Escardino y A. Blasco, “Controles de fabricación de azulejos", Ed. Soc. Esp. Ceram. Vidr., Valencia (1984).

5. G. Biffi, "Gres porcellanato. Tenologia, produzione, Mercato", Ed. Gruppo Editoriale Faenza Editrice SpA, Faenza (Italia), 1996.

6. Lamberti SpA (Italia) Patente ${ }^{\circ}$ IT-MI95A000093-20.01.95 